\title{
20. RHEOLOGY OF SERPENTINITE MUDS IN THE MARIANA-IZU-BONIN FOREARC ${ }^{1}$
}

\author{
Stephen Paul Phipps ${ }^{2}$ and Dean Ballotti ${ }^{3}$
}

\begin{abstract}
Serpentinite seamounts in the Mariana forearc have been explained as diapirs rising from the Benioff zone. This hypothesis predicts that the serpentinites should have low strengths as well as low densities relative to the surrounding rocks.

Drilling during Leg 125 showed that the materials forming Conical Seamount in the Mariana forearc and Torishima Forearc Seamount in the Izu-Bonin forearc are water-charged serpentinite muds of density $<2 \mathrm{~g} / \mathrm{cm}^{3}$. Wykeham-Farrance torsion-vane tests showed that they are plastic solids with a rheology that bears many similarities to the idealized Cam clay soil model and is well described by critical-state soil mechanics. The serpentinite muds have ultimate strengths of 1.3 to $273.7 \mathrm{kPa}$ and yield strengths of approximately 1.0 to $50 \mathrm{kPa}$. These muds thus are orders of magnitude weaker than salt and are, in fact, comparable in density and strength to common deep-sea clay muds. Such weak and low-density materials easily become diapiric. Serpentinite muds from the summit of Conical Seamount are weaker and more ductile than those on its flanks or on Torishima Forearc Seamount. Moreover, the summit muds do not contain the pronounced pure- and simple-shear fabrics that characterize those on the seamount flanks.

The seamounts are morphologically similar to shield volcanoes, and anastomosing serpentinite debris flows descending from their summits are similar in map view to pahoehoe flows. These morphologic features, together with the physical properties of the muds and their similarities to other oceanic muds and the geochemistry of the entrained waters, suggest that many forearc serpentinite seamounts are gigantic (10-20 km wide, $1.5-2.0 \mathrm{~km}$ high) mud volcanoes that formed by the eruption of highly liquid serpentinite muds.

Torishima Forearc Seamount, which is blanketed by more "normal" pelagic/volcaniclastic sediment, has probably been inactive since the Miocene. Conical Seamount, which seems to consist entirely of serpentinite mud and is venting fresh water of unusual chemistry from its summit, is presently active. Muds from the flanks of Conical Seamount are stronger and more brittle than those from the summit site, and muds from Torishima Forearc Seamount are stronger yet; this suggests that the serpentinite debris flows are compacted and dewatered as they mature. The shear fabrics probably result from downslope creep and flow, but may also bẹ inherited.
\end{abstract}

\section{INTRODUCTION}

As many as 100 seamounts up to $2 \mathrm{~km}$ high and $30 \mathrm{~km}$ wide dot the outer part of the Mariana forearc, 50 to $120 \mathrm{~km}$ from the trench axis (Fryer et al., 1985; Fryer and Fryer, 1987). Similar seamounts mark the trench-slope break in the Izu-Bonin forearc to the north (Taylor and Smoot, 1984; Horine et al., 1990). Geophysical surveys, dredging, ALVIN dives, and drilling have shown that at least some, and perhaps many, of these seamounts are composed largely of serpentinite (Hussong and Fryer, 1982; Bloomer, 1983; Fryer et al., 1985; Fryer and Fryer, 1987). Drilling on two of the seamounts during Ocean Drilling Program (ODP) Leg 125 showed that they consist of blocks of serpentinite, basaltic igneous rocks, and rare sedimentary and meta-igneous rocks ranging from sand-sized to more than $20 \mathrm{~m}$ wide, entrained in a matrix of amorphous to phacoidal, unsheared to highly sheared serpentinite mud (Fryer et al., 1990). If relatively unsheared, these materials were referred to in the Leg 125 Proceedings of the Ocean Drilling Program, Initial Results volume (Fryer, Pearce, Stokking, et al., 1990) as "serpentine" modified by adjectives from the Wentworth-Shepard grain-size classification; if dominated by an anastomosing shear fabric, they were described as "sheared phacoidal serpentine." All these materials are here grouped as "serpentinite muds."

A model proposed by Fryer et al. (1985) explains these seamounts as serpentinite diapirs. It has long been believed that serpentinite, like salt, can rise diapirically into denser overlying rocks. To be diapiric in this strict sense (a process termed buoyancy halokinesis by some

\footnotetext{
'Fryer, P., Pearce, J. A., Stokking, L. B., et al,, 1992. Proc. ODP, Sci. Results, 125: College Station, TX (Ocean Drilling Program).

${ }^{2}$ Geology Department, University of Pennsylvania, 240 S. 33rd Street, Philadelphia, PA 19104-6316, U.S.A.

${ }^{3}$ Department of Earth and Atmospheric Sciences, Purdue University, West Lafayette, IN 47904, U.S.A.
}

students of salt domes-e.g., Jackson and Talbot, 1986), a low-density material of low strength must be confined beneath a higher density material. Serpentinites with other physical properties may be emplaced by other mechanisms (Phipps, 1984a, 1984b; Phipps and Shipboard Party, 1990). Thus, along with density and other physical properties, the strength of the serpentinite becomes an important constraint on the processes that formed the Mariana-Izu-Bonin forearc seamounts.

The problem of serpentinite strength is also one of general interest in structural geology and geotectonics because serpentinites have been found at high levels of the oceanic crust in several plate tectonic environments, in both modern and fossil occurrences. An understanding of serpentinite mechanics is especially important for studying the evolution of subduction zones and fracture zones, where serpentinite outcrops are particularly abundant. Perhaps most interesting in the light of the Mariana-Izu-Bonin seamounts are serpentinite occurrences in fossil forearcs, such as those in the California Coast Ranges, where serpentinite-rich olistostromes overlie forearc basement and underlie more "normal" arc-derived volcanogenic sediments (Phipps, 1984a, 1984b).

Previous work on serpentinite strength includes the pioneering experimental studies of Handin (1964) and Raleigh and Paterson (1965) on massive serpentinites, which found that these rocks have strengths comparable to granite. In these conventional triaxial deformation tests, massive serpentinites failed at deviatoric stresses of $300-1100 \mathrm{MPa}(3-11 \mathrm{kbar})$ at low temperatures (less than $\left.300^{\circ} \mathrm{C}\right)$. Under low confining pressures, less than $350 \mathrm{MPa}(3.5 \mathrm{kbar})$, the rocks deformed brittlely; at higher confining pressures of 350 to $500 \mathrm{MPa}$ (3.5 to $5 \mathrm{kbar}$ ), they behaved ductilely. Massive serpentinites, however, are weakened and embrittled drastically by serpentine dehydration reactions at temperatures above $300^{\circ} \mathrm{C}$. In a field study in the California Coast Ranges, Cowan and Mansfield (1970) analyzed the shapes of lobate debris flows of phacoidal serpentinite in longitudinal cross section and concluded that the effective long-term 
shear strength of sheared rocky serpentinite is much lower, approximately 80 to $300 \mathrm{kPa}$.

In this paper, we present preliminary data about the mechanical behavior of a third type of serpentinite, the hydrated serpentinite muds drilled in the Mariana and Izu-Bonin forearcs during the spring of 1989 by the scientists of Leg 125 . We drilled at five localities on serpentinite seamounts: Sites 778 and 779 on the flanks of Conical Seamount in the Mariana forearc and Site 780 on its summit and Sites 783 and 784 on the flanks of Torishima Forearc Seamount in the Izu-Bonin forearc. We also present for comparison data from more normal oceanic clay muds of pelagic and volcaniclastic origin from Sites 781,783 , and 784 . Our results show that the stress-strain behavior of all these muds conforms generally to the pattern predicted by critical-state soil mechanics; in particular, it is similar to that of Cam clay, an idealized elastic-plastic soil model. An especially important result is that the serpentinite muds that make up the seamounts are extremely weak plastic solids, comparable in strength to other oceanic muds. When combined with the density data gathered during the cruise, these results demonstrate that serpentinite diapirism, in the strict sense, is a likely mechanism for emplacing the seamounts, which essentially appear to be gigantic serpentinite mud volcanoes.

\section{METHODS}

\section{Apparatus}

Our measurements were performed using a Wykeham-Farrance torsion-vane apparatus, as described by Boyce (1977). In this device, an electric motor rotates a shaft, on the lower end of which is a small, four-bladed metal vane or paddle, which is embedded in the sample. The drive is not direct, but operates through an O-ring, which rotates a calibrated, helical spring that in turn drives the rotating vane. The sample resists the rotation of the vane, causing the spring to tighten under the torsional force applied by the driving motor. This continues until the force in the spring overcomes the resistance of the sample, rotating the vane. The amount of vane rotation is measured on one scale at the top of the shaft, and the amount of spring rotation (tightening) on another. Because the spring constant is known, the force applied to the vane can be calculated, and because the dimensions of the blades are known, the stress required to cause the measured vane rotation can then be calculated from the force. The device thus effectively measures rotational strain and torsional force, which through a computational algorithm is translated into "shear stress."

Typically, little strain was accomplished by initial increments of stress, but as stress built up in the spring, the vane rotated more and more freely until constant continuing stress produced indefinitely continuing rotation. We measured the stress at increments of the strain angle, until the maximum stress sustained by the sample was reached. Some samples failed catastrophically, causing sharp decreases in the applied stress; for this eventuality, the apparatus is equipped with a slip ring and pointer that mark and preserve the record of the highest stress reached.

\section{Measurement Techniques}

The freshly cut working half of the core was brought to the torsionvane table immediately after the paleomagnetic measurements were performed. We selected appropriate test sites within the core and gently lowered the torsion vane into the sample until the blade was completely buried within it. We placed the blade in the longitudinal middle of the core, well above the core liner, to minimize edge effects from the liner (frictional coupling between the sample and liner). We were also careful to avoid large clasts suspended in the muds.

We measured the stress at set increments of the strain angle, typically $1^{\circ}$ and $5^{\circ}$ of vane rotation and then every $5^{\circ}$ until the vane rotated freely at the same stress level for at least three strain increments. For strong samples, stress was measured at every degree of strain for the first $5^{\circ}$ to $10^{\circ}$. Whenever possible, readings were taken by two operators: one read the stress dial, while the other read the strain dial and called for stress readings at the appropriate strain increments and recorded the data. In these circumstances, readings were probably accurate to $0.5^{\circ}$. Other demands on personnel sometimes made it necessary to conduct readings with only one person; these are probably accurate only to $1^{\circ}$ or $2^{\circ}$.

After runs were completed, we examined the core to further determine the deformation mechanism. The more indurated muds, or those that became desiccated aboard ship before testing, tended to exhibit catastrophic failure with stress drops; observation showed that many of these materials failed by macroscopic brittle cracking. In these cases, the stress levels reached just before the stress dropped abruptly represent failure strengths. In most instances, these corresponded to maximum (ultimate) strengths. Wetter and less indurated muds exhibited a gradual or asymptotic approach to maximum strengths as the strain angle increased, without catastrophic failure; observation showed no macroscopic cracking or other signs of failure. Rather, the material seemed to be capable of flowing to accommodate continuing strain. In these measurements, the maximum strengths correspond simply to the ultimate strengths. In some samples, however, examination showed that the rotating vane had excavated a cylindrical minicore of material from the core half, and that this, with the vane embedded in it, was rotated by the shaft/spring assembly. In these cases, the constant resistance to turning thus was a result of friction between the cylindrical wall of the rotating minicore and the rest of the sample.

Measurements were conducted at room temperature $\left(\sim 22^{\circ} \mathrm{C}\right)$ and pressure $\left(\mathrm{P}_{\text {conf }}=100 \mathrm{kPa}=1 \mathrm{bar}\right)$. The vane in the shipboard apparatus is set to turn at $89 \% \mathrm{~min}$ when rotating freely, compared with the usual rate of $6 \% \mathrm{~min}$. This rapid rotation rate is an attempt to ensure that the sample is "undrained," that is, that pore fluid expulsion by the rotating vane is not an important strain mechanism (Boyce, 1977, p. 1060, and references therein). In our experiments, we did not perform remolded strength tests.

The "shear strengths" reported here thus correspond to either ultimate strengths or failure strengths, depending on the ductility of the sample, measured at $\mathrm{P}_{\text {conf }}=100 \mathrm{kPa}$. Unless otherwise stated, this is the meaning of the term "strength" throughout this paper.

\section{Data Reduction}

The raw data-strain and spring angles-were entered into the shipboard VAX computer system using the IBM PC terminal in the physical-properties area of the laboratory and the PHYSPROPS data-entry and data-reduction program, with which we calculated and reported the stresses for each spring angle. We entered not only the data for ultimate and/or failure strength, but also that for each incremental strain and stress. This process, although laborious, allowed us to produce stress-strain curves for each test, which are far more revealing about mechanical behavior than simple strength measurements. After entry and reduction, the data were downloaded to the shipboard Macintosh computers and processed and displayed using Microsoft Excel and Computer Associates Cricket Graph.

\section{Sampling Protocols}

We attempted to test the cores as soon as possible after they were recovered and cut, because dehydration radically affects the mechani$\mathrm{cal}$ properties of these muds. We were, however, unable to perform timely measurements on cores from Sites 778 and 779 or on those from the early holes of Site 780. When we retrieved these cores from storage for testing later during the cruise, they were clearly desiccated, probably largely from exposure during description and sampling. Despite standard packaging in sealed D-tubes with wet sponges, desiccation may have continued during storage. Strength measurements reflected this desiccation: these cores were generally stronger than similar ones that we measured promptly and most failed brittlely, 
with macroscopic cracking. Most of this chapter, therefore, is devoted to our measurements of cores from Hole 780D and Sites 783 and 784 .

We attempted to make at least one measurement in every core section $(1.5 \mathrm{~m})$ that contained serpentinite muds, but tested texturally variable intervals more frequently. We attempted to test pelagic/ volcanogenic sediments at least once per core $(7.5 \mathrm{~m})$. The top section or two in each hole was typically a slurry of mud and seawater if rotary cored; we did not measure these totally disturbed materials.

\section{DATA}

Tables 1- 4 present the ultimate and failure strengths of serpentinite muds from Holes 780D, 783A, and 784A and Site 779. Figure 1 depicts representative stress-strain curves of these muds. For comparison, Tables 2,3 , and 5 show representative strengths of pelagid volcaniclastic sediments, and Figure 2 shows representative stressstrain curves.

The stress-strain curves of almost all muds we studied show that each increment of stress yields somewhat more strain. This behavior is typical of plastic materials; at high strains, the most ductile muds, which did not experience brittle failure, approximate ideal plastics. In ideal plastics, any stress above the minimum required to cause nonrecoverable deformation causes continuing strain, mimicking the behavior of viscous materials. An important measure of rheology in plastic solids is the ultimate strength, the greatest strength achieved by the material. In most of our tests, the ultimate strength of highly ductile materials corresponded to the highest stress maintained during "viscous" behavior at the end of the test. The ultimate strength of more brittle materials corresponded to the failure strength.

In addition to the ultimate strength, an important parameter in plastic mechanics is the yield strength, which marks the onset of major nonrecoverable (inelastic) strain. Yield strength is typically seen on the stress-strain curve as the first significant deflection from a linear stress-strain relationship. In many of our test results, the deviation from linear stress-strain behavior is gradual; thus, determining yield strength is difficult (Figs. 1 and 2). Reasonable values seem to be about $20 \%$ to $50 \%$ of the ultimate strengths. As later discussion will

Table 1. Ultimate and failure strengths of serpentinite muds from Hole 780D.

\begin{tabular}{lrr}
\hline Section & $\begin{array}{c}\text { Depth } \\
\text { (mbsf) }\end{array}$ & $\begin{array}{c}\text { Strength } \\
(\mathrm{kPa})\end{array}$ \\
\hline $125-780 \mathrm{D}-$ & & \\
& & \\
$1 \mathrm{X}-3$ & 1.91 & 14.5 \\
$2 \mathrm{X}-2$ & 3.07 & 7.1 \\
$2 \mathrm{X}-2$ & 3.07 & 7.3 \\
$2 \mathrm{X}-\mathrm{CC}$ & 3.87 & 16.4 \\
$2 \mathrm{X}-\mathrm{CC}$ & 3.89 & 18.1 \\
$2 \mathrm{X}-\mathrm{CC}$ & 3.90 & 20.1 \\
$3 \mathrm{X}-1$ & 12.07 & 37.5 \\
$6 \mathrm{X}-1$ & 21.00 & 9.1 \\
$6 \mathrm{X}-2$ & 21.39 & 2.7 \\
$6 \mathrm{X}-2$ & 21.52 & 5.2 \\
$6 \mathrm{X}-2$ & 21.63 & 3.8 \\
$6 \mathrm{X}-2$ & 21.64 & 4.0 \\
$7 \mathrm{X}-1$ & 27.55 & 7.1 \\
$7 \mathrm{X}-1$ & 27.63 & 7.5 \\
$7 \mathrm{X}-1$ & 27.80 & 11.7 \\
$7 \mathrm{X}-1$ & 27.86 & 26.9 \\
$7 \mathrm{X}-1$ & 27.97 & 24.6 \\
$7 \mathrm{X}-1$ & 28.01 & 18.6 \\
$7 \mathrm{X}-1$ & 27.45 & 10.0 \\
$7 \mathrm{X}-5$ & 28.52 & 3.0 \\
$7 \mathrm{X}-5$ & 28.76 & 2.2 \\
$7 \mathrm{X}-5$ & 29.27 & 1.3 \\
$7 \mathrm{X}-6$ & 30.46 & 4.2 \\
$7 \mathrm{X}-\mathrm{CC}$ & 30.74 & 8.2 \\
\hline
\end{tabular}

Note: Mean $=11.3$, standard deviation $=9.1$.
Table 2. Ultimate and failure strengths of muds from Hole 783A.

\begin{tabular}{|c|c|c|}
\hline Section & $\begin{array}{l}\text { Depth } \\
\text { (mbsf) }\end{array}$ & $\begin{array}{c}\text { Strength } \\
(\mathrm{kPa})\end{array}$ \\
\hline \multicolumn{3}{|l|}{$125-783 \mathrm{~A}-$} \\
\hline \multicolumn{3}{|c|}{ "Normal" sediments } \\
\hline IR-1 & 0.73 & 13.1 \\
\hline IR-3 & 3.70 & 37.1 \\
\hline IR-5 & 6.68 & 29.1 \\
\hline $2 \mathrm{R}-1$ & 10.93 & 17.5 \\
\hline $2 \mathrm{R}-2$ & 11.32 & 44.4 \\
\hline $4 \mathrm{R}-2$ & 28.16 & 34.9 \\
\hline $4 \mathrm{R}-4$ & 31.22 & 41.5 \\
\hline 5R-1 & 36.56 & 32.8 \\
\hline $5 R-3$ & 39.56 & 52.4 \\
\hline $7 \mathrm{R}-1$ & 53.44 & 29.8 \\
\hline $7 R-3$ & 56.28 & 69.2 \\
\hline $8 R-1$ & 62.97 & 34.9 \\
\hline \multicolumn{3}{|c|}{ Serpentinites } \\
\hline $15 R-1$ & 130.41 & 16.0 \\
\hline $15 \mathrm{R}-1$ & 130.83 & 51.0 \\
\hline $15 R-2$ & 131.87 & 16.7 \\
\hline $15 R-3$ & 133.33 & 35.7 \\
\hline $16 \mathrm{R}-1$ & 139.92 & 19.7 \\
\hline $16 R-2$ & 141.92 & 25.5 \\
\hline $16 R-3$ & 142.39 & 26.9 \\
\hline $17 \mathrm{R}-1$ & 149.97 & 41.5 \\
\hline
\end{tabular}

show, some very weak, unconsolidated and water-charged muds may have vanishingly small yield strengths.

\section{Serpentinite Muds}

The weakest muds measured were those from Hole 780D on the summit of Conical Seamount; these ranged in ultimate strength from 1.3 to $37.5 \mathrm{kPa}(0.013$ to $0.375 \mathrm{bar})$, with a mean of $11.3 \mathrm{kPa}$ (Table 1$)$. The stress-strain curves show that these materials are plastics with a high ductility; that is, they generally did not fail, but continued to deform at ultimate strength. In consonance with this behavior, visual examination of the cores after testing showed no macroscopic cracking. There is no consistent downward increase in strength; rather, some of the strongest muds occur in the top $12 \mathrm{~m}$ of the hole, and some of the weakest ones at the bottom, at depths below $25 \mathrm{~m}$. The yield strength of these muds was typically about $50 \%$ of their ultimate strength, for a mean of approximately $6 \mathrm{kPa}$.

Sheared serpentinite muds from Site 779 on the flank of Conical Seamount, tested after some desiccation, had a mean strength of 54.3 $( \pm 70.0) \mathrm{kPa}$ (range, 8.0 to $273.7 \mathrm{kPa}$ ) (Table 4). Most of the stronger samples were conspicuously desiccated and failed brittlely with largescale macroscopic cracking. If only the freshest appearing samples are included, the mean strength is $36.1( \pm 25.5) \mathrm{kPa}$ (range, 14.1 to $83.6 \mathrm{kPa}$ ). Comparison with geologically and texturally similar, but significantly older, materials from Sites 783 and 784 suggests that these values are probably of the same order as those we would have obtained had we tested the samples immediately after recovery, but are probably $20 \%$ to $50 \%$ too large. Thus, these sheared serpentinite muds from the flanks of Conical Seamount are significantly stronger than the unsheared ones from the summit. The same is true if yield strengths rather than ultimate strengths are compared.

At Sites 783 and 784 on the flanks of Torishima Forearc Seamount, the serpentinite muds were significantly stronger, showing mean ultimate strengths of 29.1 and $79.1 \mathrm{kPa}$, respectively (Tables 2 and 3). Moreover, the mean strength at Site 783 approached the maximum strength at Hole 
Table 3. Ultimate and failure strengths of muds from Hole 784A.

\begin{tabular}{|c|c|c|}
\hline Section & $\begin{array}{l}\text { Depth } \\
\text { (mbsf) }\end{array}$ & $\begin{array}{c}\text { Strength } \\
(\mathrm{kPa})\end{array}$ \\
\hline \multicolumn{3}{|l|}{$125-784 \mathrm{~A}-$} \\
\hline \multicolumn{3}{|c|}{ "Normal" sediments } \\
\hline $3 R-1$ & 11.81 & 19.7 \\
\hline $3 R-3$ & 14.71 & 43.0 \\
\hline $4 \mathrm{R}-3$ & 24.22 & 34.9 \\
\hline $6 R-1$ & 40.40 & 17.5 \\
\hline $6 \mathrm{R}-3$ & 43.33 & 29.8 \\
\hline $6 R-5$ & 46.63 & 37.9 \\
\hline $7 \mathrm{R}-1$ & 50.08 & 34.9 \\
\hline $7 \mathrm{R}-3$ & 52.82 & 18.9 \\
\hline $8 R-2$ & 60.88 & 52.4 \\
\hline $8 R-4$ & 63.94 & 40.0 \\
\hline $9 \mathrm{R}-2$ & 70.90 & 32.0 \\
\hline $9 \mathrm{R}-4$ & 73.50 & 40.0 \\
\hline $10 \mathrm{R}-2$ & 80.20 & 25.5 \\
\hline $10 \mathrm{R}-4$ & 83.40 & 24.0 \\
\hline $12 R-2$ & 99.38 & 57.5 \\
\hline 13R-1 & 107.46 & 17.5 \\
\hline $14 \mathrm{R}-2$ & 118.78 & 54.6 \\
\hline $14 \mathrm{R}-4$ & 121.56 & 57.5 \\
\hline $15 R-2$ & 128.75 & 54.6 \\
\hline $15 R-4$ & 131.65 & 72.8 \\
\hline 16R-1 & 137.00 & 43.0 \\
\hline $16 \mathrm{R}-3$ & 139.82 & 49.5 \\
\hline $16 \mathrm{R}-5$ & 142.91 & 57.5 \\
\hline 17R-3 & 149.55 & 52.4 \\
\hline $17 R-5$ & 152.60 & 85.9 \\
\hline \multicolumn{3}{|c|}{ Serpentinites } \\
\hline 37R-1 & 339.35 & 32.0 \\
\hline $37 \mathrm{R}-1$ & 339.92 & 22.6 \\
\hline $37 \mathrm{R}-2$ & 340.50 & 83.0 \\
\hline $39 \mathrm{R}-2$ & 360.35 & 52.4 \\
\hline $40 \mathrm{R}-1$ & 368.11 & 35.7 \\
\hline $40 \mathrm{R}-1$ & 368.59 & 72.1 \\
\hline $40 \mathrm{R}-1$ & 368.65 & 83.7 \\
\hline $40 \mathrm{R}-2$ & 369.15 & 251.2 \\
\hline
\end{tabular}

Note: Overall average $=51.1$, standard deviation $=40.8 ;$ serpentinites mean $=79.1$, standard deviation $=73.4$, sediments mean $=41.7$, standard deviation $=17.3$.

Table 4. Ultimate and failure strengths of serpentinite muds from Site 779.

\begin{tabular}{|c|c|c|}
\hline Section & $\begin{array}{l}\text { Depth } \\
\text { (mbsf) }\end{array}$ & $\begin{array}{l}\text { Strength } \\
(\mathrm{kPa})\end{array}$ \\
\hline \multicolumn{3}{|l|}{$125-779 \mathrm{~A}-$} \\
\hline $\mid R-1$ & 0.92 & 21.8 \\
\hline 2R-1 & 2.03 & 8.0 \\
\hline 13R-1 & 107.61 & 19.7 \\
\hline 18R-2 & 157.03 & 273.7 \\
\hline $32 \mathrm{R}-1$ & 265.55 & 22.6 \\
\hline $32 \mathrm{R}-1$ & 265.77 & 34.9 \\
\hline $32 R-2$ & 266.69 & 142.7 \\
\hline $36 \mathrm{R}-2$ & 304.64 & 9.2 \\
\hline $36 \mathrm{R}-2$ & 305.26 & 83.6 \\
\hline $36 \mathrm{R}-2$ & 305.40 & 57.8 \\
\hline $37 \mathrm{R}-1$ & 312.87 & 38.1 \\
\hline $37 \mathrm{R}-1$ & 312.94 & 19.2 \\
\hline $37 \mathrm{R}-1$ & 313.11 & 14.1 \\
\hline \multicolumn{3}{|l|}{ 125-779B- } \\
\hline $1 \mathrm{R}-1$ & 0.08 & 34.9 \\
\hline $1 \mathrm{R}-1$ & 1.04 & 33.9 \\
\hline
\end{tabular}

Note: Site mean $=54.3$, standard deviation $=70.0$; mean of less desiccated samples $=36.1$, standard deviation $=25.5$.

Table 5. Ultimate and failure strengths of "normal" clay muds from Hole 781A.

\begin{tabular}{crr}
\hline Section & $\begin{array}{c}\text { Depth } \\
(\mathrm{mbsf})\end{array}$ & \multicolumn{1}{c}{$\begin{array}{c}\text { Strength } \\
(\mathrm{kPa})\end{array}$} \\
\hline 125-781A- & & \\
& & \\
1R-2 & 1.74 & 8.1 \\
1R-2 & 2.08 & 12.8 \\
1R-3 & 2.65 & 7.5 \\
6R-3 & 48.08 & 8.7 \\
6R-3 & 49.13 & 35.9 \\
6R-4 & 50.18 & 116.1 \\
6R-4 & 50.58 & 75.3 \\
6R-5 & 51.01 & 33.9 \\
\hline
\end{tabular}

Note: Mean $=37.3$, standard deviation $=39.3$.

$780 \mathrm{D}$, and the mean strength at Site 784 was greater than the maximum at Site 783. This is so even if one anomalously strong material is excluded (Section 125-784A-40R-2, $15 \mathrm{~cm}$; strength, $251.2 \mathrm{kPa}$; see Fig. 3), yielding a mean strength of $54.5 \mathrm{kPa}$. Although the stress-strain curves also indicate that these muds are plastic solids, these distinctly stronger materials also fail brittlely, rather than deforming indefinitely at ultimate strength. Conspicuous macroscopic cracking was visible after failure in most samples. As with those at Site 780, no consistent downward increase in strength was observed in the serpentinite muds at Sites 783 or 784 (Fig. 3). Yield strengths were typically about $30 \%$ of ultimate strengths, or 10 to $25 \mathrm{kPa}$.

\section{Pelagic/Volcaniclastic Sediments}

In addition to their intrinsic interest, the laboratory rheologies of the more normal sediments we drilled are important because they can be compared to those of the serpentinite muds. Such comparison then allows us to use the behavior of normal muds at geologic conditions, which is comparatively well understood, to draw inferences about the geologic behavior of serpentinite muds, about which we know essentially nothing.

Because Conical Seamount may consist almost entirely of serpentinite mud, the nearest and probably most relevant measurements of the strength of normal muds come from Site 781, about $5 \mathrm{~km}$ northwest of the base of the seamount. Because of poor recovery, only
Cores 125-781A-1R and 125-781A-6R were tested at this site. Of these, three young (late Pleistocene) pelagic silty clays to clayey silts from Core $125-781 \mathrm{~A}-1 \mathrm{R}$ are probably the most directly comparable to the muds from Conical Seamount and especially to those from Site 780, which are similar in age, grain size, and texture. The Site 781 muds had a mean strength of $9.5( \pm 2.9) \mathrm{kPa}$ (Table 5) and are thus similar in strength to those from Hole 780D. Moreover, their mechanical behavior is similar: both are weak, plastic, and highly ductile (Figs. 1 and 2). Deeper in the hole at Site 781, lower Pleistocene muds rich in sand-sized ash grains are stronger and have a much wider range in strength, from 8.7 to $116.1 \mathrm{kPa}$, with a mean of $39.3 \mathrm{kPa}$ (Table 5).

At Sites 783 and 784, the most valuable comparisons come from the 130 and $340 \mathrm{~m}$ (respectively) of normal pelagic/volcanogenic sediments that overlie the serpentinite muds. At each site, the deepernormal sediments are lithified - they are consolidated and cohesive and exhibit "biscuiting" fractures due to drilling, presumably because of compaction and weak cementation. These partially lithified normal muds, however, give way abruptly to unlithified - uncemented and much less consolidated - serpentinite muds beneath. Partially lithified pelagic/volcanogenic sediments occupy the intervals between 62.1 and $120.0 \mathrm{~m}$ below seafloor (mbsf) at Site 783 and between 126.4 and $312.1 \mathrm{mbsf}$ at Site 784 . The partially lithified sediments are mechanically different - much more brittle and presumably stronger - than the underlying serpentinite muds, which are more like the unlithified normal muds in the upper part of the section. There 


\section{Comparative Deformation Behavior:} Serpentinite Muds

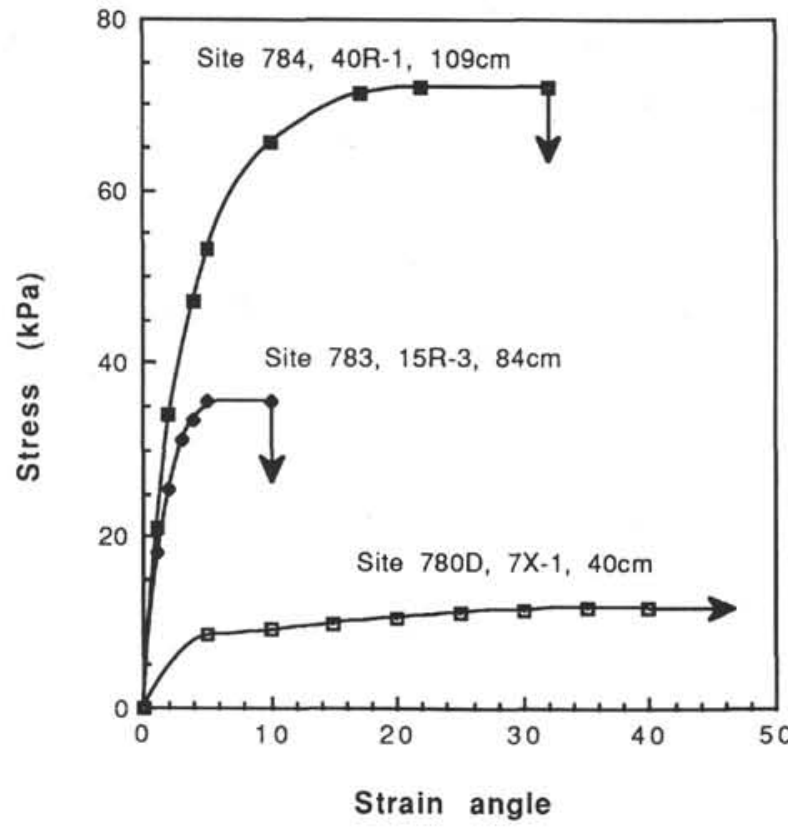

Fail. str. $72.1 \mathrm{kPa}$

Fail. str. $35.7 \mathrm{kPa}$

Ult. str. $11.7 \mathrm{kPa}$

Figure 1. Comparative stress-strain behavior and strengths of serpentinite muds from Leg 125 .

\section{Comparative Deformation Behavior: "Normal" Muds}

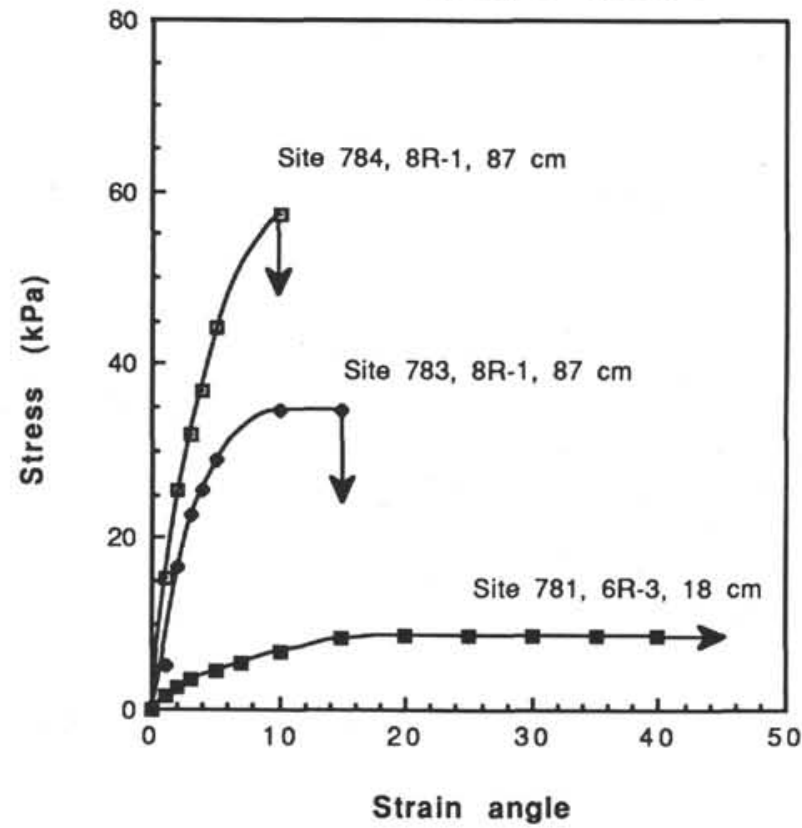

Fail. str. $57.5 \mathrm{kPa}$

Fail. str. $34.9 \mathrm{kPa}$

Ult. str. $8.7 \mathrm{kPa}$

Figure 2. Comparative stress-strain behavior and strengths of normal pelagic/volcanogenic muds from Leg 125.

are no strength data for the most lithified sediments because they are too diagenetically indurated for us to perform torsion-vane tests - that is, inserting the vane is impossible or causes the sample to fracture or shatter.

The unlithified muds exhibited strengths and stress-strain curves generally comparable to those of the serpentinite muds (Tables 1 through 5 and Figs. 1 and 2). At Site 783, the unlithified lower Pliocene to Pleistocene pelagic/volcanogenic clays, silty clays, and clayey silts were on average somewhat stronger than the underlying serpentinites: strengths ranged from 13.1 to $69.2 \mathrm{kPa}$, with a mean of $36.4( \pm 14.9) \mathrm{kPa}$ (Table 2). At Site 784 , on the other hand, the unlithified muds were somewhat weaker than the serpentinites. 


\section{Site 784: Ultimate strength vs. Depth}

STRESS ( $\mathrm{kPa})$

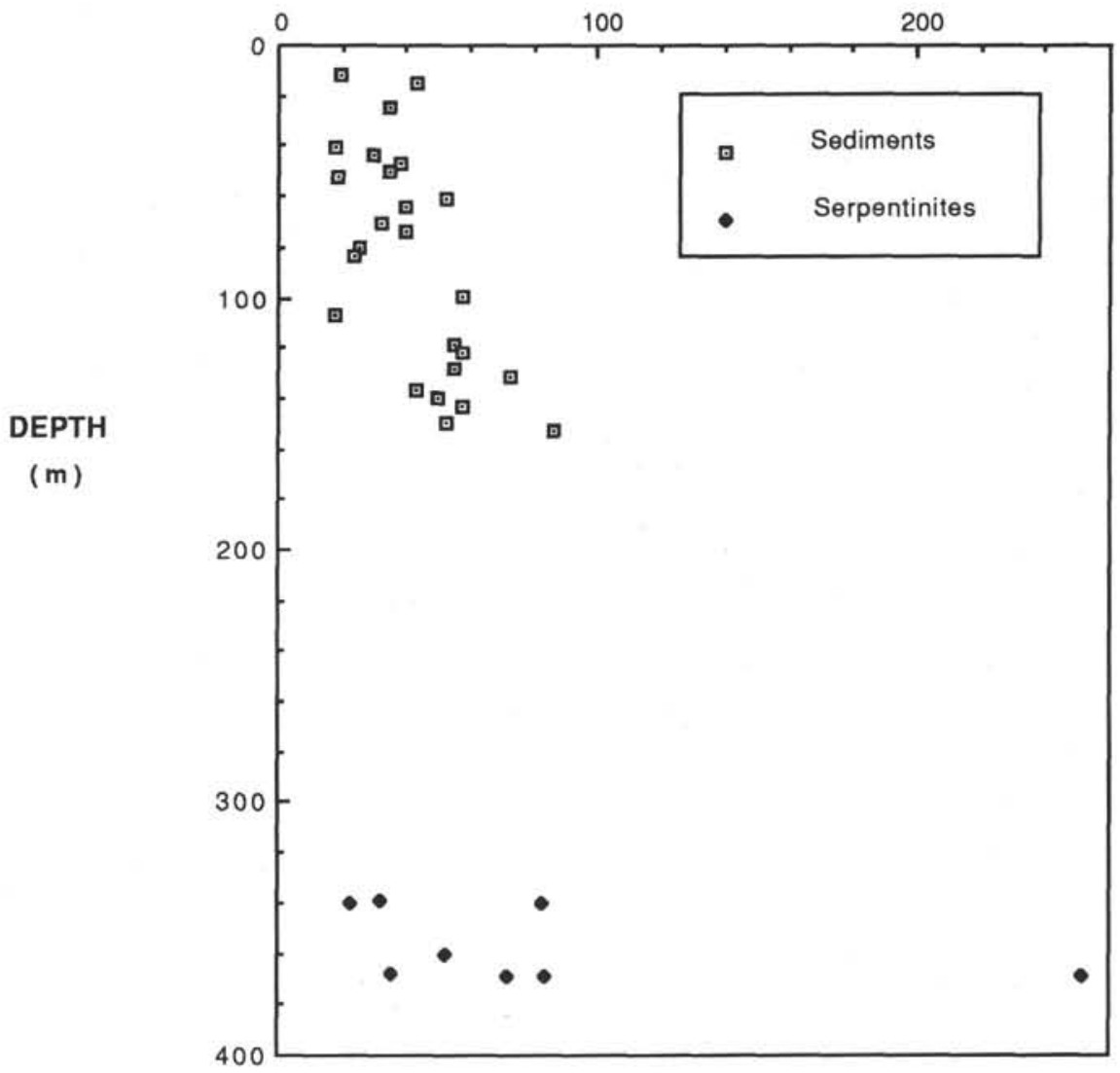

Figure 3. Strength-depth relationships at Site 784. Strengths of normal muds increase downward; strengths of serpentinite muds do not.

Eleven Pliocene and Pleistocene volcanogenic/pelagic clayey silts and silty clays had a mean strength of $32.8( \pm 10.9) \mathrm{kPa}$, whereas eight upper Miocene clays were somewhat stronger, with a mean strength of $38.6( \pm 16.2) \mathrm{kPa}$ (Table 3$)$. Seven weakly lithified claystones from between 126.4 and 153 mbsf at Site 784 had a mean strength of 59.4 $( \pm 14.8) \mathrm{kPa}$, comparable to the strength of the underlying serpentinite muds. Overall, the strengths of the normal muds and partially lithified mudstones at Site 784 varied from 17.5 to $85.9 \mathrm{kPa}$, with a mean of $41.7 \mathrm{kPa}( \pm 17.3) \mathrm{kPa}$ (Table 3 and Fig. 2).

Unlike the serpentinite muds, there is some downward increase in strength in the normal sediments at Site 783, and at Site 784, where the sediment section is almost 3 times as thick, the downward strength increase is obvious (Fig. 3). Moreover, the topmost serpentinite muds at Site 784 are much weaker than the overlying lithified siltstones and claystones and, furthermore, are weaker than the deepest normal sediments measured, $150 \mathrm{~m}$ above. Moreover, their strengths show a much wider scatter, spanning in a small depth interval essentially the entire strength range of the normal sediments (Fig. 3). Stress-strain curves show that the pelagic/volcaniclastic sediments exhibit plastic behavior; they are stronger and more brittle at depth than near the surface (Fig. 2).

\section{DISCUSSION}

\section{Limitations of Data}

There are several caveats to consider in interpreting the data we report here. One difficulty is the unknown extent to which drilling disturbance has altered the structure and mechanical behavior of the materials tested. Raising, handling, and sawing the core may also disturb it, as may the exsolution of dissolved gases as the core decompresses (Karig, 1986). The amount of disturbance is difficult to quantify, especially for the foliated serpentinite muds with lensoid fabrics that we termed sheared phacoidal serpentine (Fryer, Pearce, Stokking, et al., 1990). In some intervals (e.g., Sections 125-778A-11R-1 and $125-778 \mathrm{~A}-13 \mathrm{R}-1$ ), the shear fabric shows some symmetry about the core axis (Fryer, Pearce, Stokking, et al., 1990, fig. 8, p. 111), and Y. Lagabrielle (pers. comm., 1990) reported that in horizontal cuts through the core the fabric is crudely radially symmetric about the axis. However, other intervals show no suspicious symmetries with respect to the core orientation, and the shear fabric even in the suspect areas is not qualitatively different from that elsewhere. Moreover, the horizontally layered serpentinite muds from Site 780 and the uppermost part of the serpentinite section at Site 784 are bowed moderately downward only at the core edges, in a manner similar to that of horizontal laminations in normal sediments. In addition, few signs of bubbles, open cavities, or other indications of outgassing sufficient to disrupt the sample fabric were seen. We therefore tentatively assert that drilling disturbance has not radically altered the mechanical properties of the materials we studied, although its effects on their fabric geometry may be rather greater. However, M. Jones (pers. comm., 1990) pointed out that the mechanical properties of some unconsolidated particulate materials are affected by sampling disturbance too minute to be visually detectable. Resolution of this problem must await more advanced 
drilling and testing techniques, as core disturbance is simply unavoidable with present methods and technology.

A central problem in applying most experimental rock-deformation results to the geologic world is that the lowest strain rate achievable in the laboratory is typically many orders of magnitude larger than the rates probably operative in nature. This is important because strain rate quantitatively and qualitatively influences material behavior in crystalline materials (Kirby and McCormick, 1989), although recent work shows that these influences are negligible for many particulate materials (M. Jones, pers. comm., 1990). Although virtually nothing is known about the strain rates involved in emplacing forearc serpentinite seamounts, it is possible that the $89 \% \mathrm{~min}$ rotation of a centimeter-sized torsion vane causes much more rapid strain in our samples than they experienced beneath the seafloor. However, it may be of the same order or even slower than the strain rates of the serpentinite debris-flow processes, and in some scenarios, the serpentinite-emplacement rates may approximate these.

It is virtually certain that the serpentinite muds will be subject to creep, i.e., slow plastic deformation at stresses well below the yield or ultimate strength as measured in the laboratory. Many clay muds experience creep, typically at a rate that declines logarithmically with time (e.g., Hyde and Burke, 1988). If the serpentinite muds rise to the seafloor relatively slowly, creep may be an important mechanism in their ascent; after they are deposited on the seafloor, it may significantly modify the shapes of the seamount edifices. Without better knowledge of the natural processes and further, more sophisticated testing, evaluatation of these possibilities is not feasible.

A fundamental limitation of the shipboard torsion-vane apparatus is that measurements must be performed at zero confining pressure (or, more precisely, $100 \mathrm{kPa}$ ). This is clearly ungeologic, and in the present case means that the muds cannot be tested at the conditions on the seafloor, let alone those within the seamount or at any depth below it.

Testing at room pressure means that the dependence of strength on pressure cannot be studied. This dependence is quite different for different mechanical types of materials. In Coulomb materials, apparently good models for many geologic situations, the dominant strain mechanism is failure that is governed by a pseudo-frictional law, with strength having a fixed value at zero pressure (the cohesion) and then increasing linearly with effective confining pressure. After failure, many Coulomb materials continue to deform by true frictional behavior, with sliding along a discontinuity surface: the stress required for continued strain again is linearly dependent on confining pressure. For a Coulomb material that fails abruptly, the shear strength measured by the torsion-vane apparatus is essentially the cohesion.

However, many geologic materials deform ductilely: the Coulomb failure law is not an appropriate way to view them. Their deformation is dominated by plastic and viscous strain mechanisms, which show little or no pressure dependence (Kirby and McCormick, 1989). Salt, for instance, is a crystalline material that is strengthened very little by increasing confining pressure (Jackson and Talbot, 1986). For such materials, the shear strength measured by the torsion-vane apparatus at the surface may approximate the ultimate strength or failure strength at depth.

Soils are particulate materials that may provide better insight into the behavior of the serpentinite muds than do crystalline materials. Soil strengths are related not only to the confining pressure but to the void ratio of the material and to the behavior of pore fluids in the voids (Bolton, 1979; Wood, 1990).

Thus, the extent to which zero-pressure strength measurement limits the scope of geologic interpretation depends crucially on the rheology of the material.

\section{Rheology of Muds}

We think that the ductile-shear fabrics, extremely low ultimate and yield strengths, plastic stress-strain behavior, and high ductility of most of the serpentinite muds we studied provide strong evidence that their deformation has been dominated by plastic and/or viscous strain mechanisms. The Coulomb failure law-successful in describing much of the deformation of the brittle upper crust-is an inappropriate way to view the rheology of such materials because Coulomb failure has not been an important strain mechanism in their deformation.

Critical-state soil mechanics, and, in particular, the Cam clay material model, probably provide more appropriate tools to interpret the stressstrain behavior of the muds we studied (Wood, 1990; M. Jones, pers. comm., 1990). Although detailed interpretation must await later publications, in broad view critical-state soil mechanics states that continuing shear strain will transform the soil into an equilibrium state at which it can shear indefinitely at a specific void ratio and at constant deviatoric stress - that is, at an ultimate strength like that observed in our samples (Bolton, 1979; Wood, 1990). The equilibrium void ratio and the ultimate strength - the deviatoric stress at which critical state is reached-as well as the yield strength will be determined in part by the consolidation history of the sample, which is in turn controlled by the greatest effective mean stresses to which it has previously been exposed (Wood, 1990).

A sample of freshly erupted serpentinite mud, for instance, will be essentially unconsolidated and will show yielding and plastic behavior as soon as deviatoric stresses are applied. This seems to be the behavior of the serpentinite muds from Site 780 on Conical Seamount (Fig. 1), as well as of the relatively shallowly buried normal mud from Site 781 (Fig. 2). Somewhat more consolidated (in soil-mechanics terminology, "moderately overconsolidated") muds, such as the serpentinite muds from the holes on the seamount flanks, have been buried and dewatered; they exhibit some elastic behavior and have higher yield and ultimate strengths than the unconsolidated muds. The samples from Sites 783 and 784 shown on Figure 1 are examples. Finally, heavily overconsolidated muds such as those from deep in holes at flank sites will exhibit considerable elastic behavior and even higher yield strengths. In some cases (not illustrated here), these yield strengths correspond to peak strengths, with later strain weakening the materials to reach critical state (see Wood, 1990, p. 133). Water content and its control by prior consolidation thus seem to exercise strong control over rheology; this will be explored in later work.

In summary, the dominance of plastic strain mechanisms in the deformation of the muds studied here shows that they do not exhibit the pressure-dependent brittle failure behavior of Coulomb materials. Rather, their rheology is similar to that of clay-rich soils and to that of the Cam clay ideal model in particular. The high water contents of the muds we studied show that effective stresses within them are likely to be quite low even at the pressures obtained at the seafloor or below it; these materials should reach critical state and ultimate strength at similar deviatoric stresses at depth or at the surface. Yield strengths will vary depending on the prior consolidation history of the materials. Thus, we think that our strength values provide reasonable (order of magnitude?) estimates of their behavior at elevated pressure, albeit at laboratory strain rates. In these materials, high-stress, highstrain-rate behavior will be controlled by the ultimate strength, whereas low-stress, slow deformation will be controlled by creep at the yield strength, or at even lower stresses for truly slow strains. Our results thus provide either reasonable rough estimates of the strength of the materials or upper bounds. We have taken two whole-round samples (short sections of the entire core) from the serpentinite muds for future triaxial stress-strain studies in order to constrain further the pressure and strain-rate dependence of strength.

\section{Value of Comparison between Normal and Serpentinite Muds}

Moreover, the stress-strain data for serpentinite muds are valuable because they can then be compared to normal pelagic/volcanogenic muds, for which the range of behavior in geologic situations is better 
known and the mechanical properties have been studied more. This comparison probably is valid because the materials are similar-both are soupy to pasty slurries of fine- to very-fine-grained sheet silicates mixed with substantial amounts of interstitial water. Even the sheared serpentinite muds are similar in constitution and fabric to sheared normal muds found in landslides, mud diapirs, and olistostromes and other mélanges.

\section{Serpentinite Diapirism}

An important goal of this research was to determine whether the serpentinite seamounts could be diapirs in the strict sense of the term, that is, whether their emplacement could have been caused by ductile flow driven by density inversion. Although many serpentinite bodies around the world have been alleged to be diapiric, serpentinite diapirism is problematic, especially if the overlying rocks are sedimentary (Phipps, 1984a, 1984b). Many serpentinites have densities of 2.40 to $2.59 \mathrm{~g} / \mathrm{cm}^{3}$, and thus are denser than most sedimentary rocks, although typically not as dense as the mafic oceanic crust (Coleman, 1971; Kirby and McCormick, 1989). A more difficult problem for oceanic occurrences is that the massive serpentinites that would be formed by hydrating ultramafic cumulates or tectonites are as strong as granites, with ultimate strengths of 300 to $1100 \mathrm{MPa}$ (Handin, 1964; Raleigh and Paterson, 1965). Serpentinites at confining pressures of more than $300 \mathrm{MPa}(3 \mathrm{kbar})$ exhibit some plastic behavior, but fail after about $8 \%$ linear strain, and have yield strengths of $1000 \mathrm{MPa}$ ( $10 \mathrm{kbar}$ ) or more, about $90 \%$ of their ultimate strengths (Handin, 1964; Raleigh and Paterson, 1965). Materials this strong are unlikely to become diapiric no matter what the density contrast. Serpentinite strength can be sharply lowered by heating the rocks to the serpentine breakdown temperature $\left(350^{\circ} \mathrm{C}\right.$ ) (Raleigh and Paterson, 1965), but such temperatures are unlikely to be achieved regionally in oceanic forearcs at depths above $15 \mathrm{~km}$. It was thus clear at the beginning of Leg 125 that if the seamounts were diapirs, the strength - and possibly the density - of the serpentinite must have been drastically reduced. Alternatively, if the seamounts were composed largely of massive serpentinite-or of little-serpentinized peridotite - the mechanism responsible for emplacing them was probably not diapirism.

The rheologic data we report here, together with other data gathered during Leg 125 , show that it is not only possible but likely that the Mariana-Izu-Bonin forearc seamounts are diapirs. In the first place, the density of the water-saturated serpentinite muds is 1.7 to $1.8 \mathrm{~g} / \mathrm{cm}^{3}$, compared with 2.5 to $3.0 \mathrm{~g} / \mathrm{cm}^{3}$ for typical components of the mafic oceanic crust (Fryer, Pearce, Stokking, et al., 1990; Kirby and McCormick, 1989). This 0.7 to $1.3 \mathrm{~g} / \mathrm{cm}^{3}$ contrast is far greater than the 0.1 to $0.4 \mathrm{~g} / \mathrm{cm}^{3}$ difference in density between salt, which has well-known diapiric behavior, and the sedimentary rocks into which it typically rises.

The serpentinite muds we studied are 5 orders of magnitude weaker than the massive serpentinites and, moreover, have ultimate strengths 3 to 4 orders of magnitude weaker than salt. The yield strength of salt is hard to estimate, but may range from perhaps 100 times stronger than serpentinite mud to somewhat weaker (Jackson and Talbot, 1986). The strengths of the serpentinite muds are similar to those of the normal muds we tested, which are of types that are commonly diapiric in accretionary prisms and rapidly subsiding basins (Westbrook and Smith, 1983; Barber et al., 1986; Barber and Brown, 1988).

The stress-strain curves also show that the serpentinite muds can enjoy large strains without brittle failure, especially in the case of the muds from Site 780 on the summit of Conical Seamount. This is important because the serpentinites must rise upward for distances of at least several kilometers, and possibly much more, if the seamounts are diapirs.

\section{Serpentinite Seamounts: Giant Mud Volcanoes}

Perhaps the most spectacular evidence of mud diapirism in accretionary prisms is the phenomenon of mud volcanoes, constructional edifices formed when water-saturated, low-density, weak muds erupt at the surface through central vents, pool, and flow out across the ground surface like lavas (Westbrook and Smith, 1983; Barber and Brown, 1988; Barber et al., 1986). Desiccation takes the place of cooling in constructing volcanic edifices, and summit craters are commonly formed. If eruption rates are sufficient to overcome erosion (which is typically very rapid), sizeable edifices may form; the morphology of these edifices closely mimics that of magmatic volcanoes. One aspect of the saturation of these muds is that they are undercompacted at depth, that is, their pore fluids are overpressured. A related aspect, interesting in the light of the geochemical results from Leg 125, is that some fluids are rich in methane (Fryer, Pearce, Stokking, et al., 1990; Mottl and Haggerty, this volume).

Mud volcanism points to a direct analogy to serpentinite seamounts in the Mariana-Izu-Bonin forearc, suggesting that they are gigantic mud volcanoes that erupted on the seafloor. Many aspects of this model mesh elegantly with mechanisms previously suggested to explain the formation of the seamounts and the serpentinite that constitutes them (Hussong and Fryer, 1985; Fryer et al., 1985; Fryer and Fryer, 1987), as well as with structural, petrologic, and geochemical data gathered during Leg 125 (Fryer, Pearce, Stokking, et al., 1990).

In this interpretation, serpentinized peridotite in the subducting slab reaches the serpentine dehydration temperature approximately beneath Conical Seamount. Water released by dehydration rises into the base of the hanging-wall plate, which is colder than the dehydration temperature, and there hydrates the mantle peridotite wedge, forming a new body of serpentinite. Seamounts and other irregularities on the subducting slab shear this serpentinite intensely, and the sheared serpentinite mixes with still more water from the subducting slab to form a slurry of serpentine and water, in which are entrained blocks of hanging-wall serpentinite and sedimentary, igneous, and metamorphic rocks from the subducting slab.

The low-density serpentinite slurry rises toward the surface diapirically, potentially with assistance from hydrofracturing. It erupts onto the seafloor, spilling out laterally in a series of serpentinite mud flows. As these mud flows sit on the seafloor and are buried by younger flows, they compact and dewater, beginning the formation of a volcanic edifice that builds higher and higher as the eruption of serpentinite muds continues. The low plastic strength or effective viscosity of the serpentinite muds means that the slopes of the mud volcano are gentle, so that the edifice approaches the shape of a basaltic shield volcano in profile. By the stage of evolution represented by Conical Seamount, a large shield has been constructed, primarily of serpentinite debris flows. The flat summit area is marked by active eruption of fluid-charged serpentinite muds, which may fill a summit depression, spilling over its edge and flowing down the slopes as new debris flows.

Many aspects of the geology of Conical Seamount support such a model. An important basic point is that all of the serpentinites recovered by drilling on serpentinite seamounts were block-bearing serpentinite muds - in no case did we drill into massive serpentinite, or into partially serpentinized peridotite, as would be expected if the seamounts were forming by in-situ hydration of a seafloor peridotite.

The serpentinite muds recovered at the summit sites were the weakest we found, and arguably the least dewatered and compacted; moreover, they were amorphous and unsheared and contained only a faint subhorizontal stratification. On the other hand, muds from the flank sites contained dramatic shear fabrics, showing evidence for both pure and simple shear (e.g., Fryer, Pearce, Stokking, et al., 1990, figs. 9 and 10, p. 263) and showed contorted and convoluted lamination. This distribution of fabrics fits well into a picture in which 
thoroughly stirred, water-saturated "primary" serpentinite muds are erupted at the seafloor, and then have shear fabrics superimposed on them as they flow down the seamount slopes. However, it is also possible that some primary diapiric serpentinite muds rising through the feeder-vent maintain similar shear fabrics formed at their source, or acquire them during ascent.

This model also explains the morphology of the serpentinite flows observed on Conical Seamount by side-scanning sonar (Hussong and Fryer, 1985; Fryer and Fryer, 1987). The flows are elongate, extend from the summit radially outward for about $10 \mathrm{~km}$, and consist of narrow, anastomosing channels. Their map geometry is in general aspect remarkably similar to that of pahoehoe flows on basaltic shield volcanoes.

Geochemical data obtained during Leg 125 also fit well with such a model (Fryer, Pearce, Stokking, et al., 1990; Mottl and Haggerty, this volume). Fresh water of an unusual composition that has clearly been involved in serpentinization reactions is flowing out of the summit at Site 780 and is maintaining strong gradients of various components against diffusion. On the other hand, at Sites 778 and 779 on the flank of Conical Seamount, similar waters are percolating outward at a much slower rate, maintaining somewhat gentler gradients. This picture is exactly compatible with a model in which fluid-charged muds erupt from the summit of the seamount, and then dewater by compaction on its flanks.

Conical Seamount thus may be a presently active serpentinite mud volcano. This is supported by the absence of even a thin veneer of pelagic/volcaniclastic mud overlying the serpentinite at the sites where we drilled. At Torishima Forearc Seamount, however, some hundreds of meters of normal muds as old as Miocene overlie the seamount. Moreover, the serpentinite muds on the flanks of the seamount are stronger and brittler than those at Conical Seamount, probably reflecting their more advanced state of compaction and dewatering. The chemical gradients here are also gentler than those at Conical Seamount. All these aspects are compatible with the suggestion that Torishima Forearc Seamount represents an extinct, Miocene and older mud volcano that at one time was much like Conical Seamount.

About $20 \mathrm{~km}$ southeast of Conical Seamount lies Pac-Man Seamount (Hussong and Fryer, 1985; Fryer and Fryer, 1987), which is about $30 \mathrm{~km}$ wide and $1.5 \mathrm{~km}$ high and is similar to Conical Seamount in plan and cross-sectional shape. However, the morphology of the flows emanating from its summit is radically different. The central area of the seamount is a deep depression, rather than a summit, and the east side of the seamount is completely breached. The depression and breach are floored by a series of lobate serpentinite flows, the tops of which are marked by semiconcentric ridges that may be pressure ridges. Moreover, ALVIN dives have shown that the escarpment from which the innermost flow comes consists largely of rocky serpentinite (P. Fryer, pers. comm., 1989). Pac-Man Seamount may be erupting stronger (more "viscous") serpentinite muds and may be mechanically more like a dacitic cone than a basaltic shield volcano (Hussong and Fryer, 1985). Or it may have been formed by flank failure, summit collapse, and slumping of the dewatered edifice of a Conical-type seamount. Alternatively, it may have been formed by different processes entirely. We are only beginning to appreciate the nature, variety, and significance of forearc serpentinite seamounts or to understand the processes that may have formed them.

\section{CONCLUSIONS}

Serpentinite muds from seamounts in the Mariana-Izu-Bonin forearc are weak plastic materials with ultimate strengths of 1.3 to $273.7 \mathrm{kPa}$, yield strengths of about 1.0 to $50 \mathrm{kPa}$, and high ductility. These muds are comparable in mechanical behavior to normal pelagic/volcaniclastic muds from nearby sites.

The serpentinite muds are of low density and low strength and will easily become diapiric through the oceanic crust. Their behavior may be similar to that of underconsolidated, overpressured muds in accretionary prisms, which are commonly diapiric and are erupted to the surface to form mud volcanoes.

Thus, many Mariana-Izu-Bonin forearc serpentinite seamounts may represent giant serpentinite mud volcanoes, up to $20 \mathrm{~km}$ wide and $2 \mathrm{~km}$ high. Sheared serpentinite is produced deep in the subduction zone, rises diapirically through the hanging-wall slab, and is erupted into the forearc. Conical Seamount in the Mariana forearc probably represents an active serpentinite mud volcano, whereas Torishima Forearc Seamount in the Izu-Bonin forearc may represent an extinct one that has been inactive since the Miocene.

\section{ACKNOWLEDGMENTS}

We are grateful to the crew and to all of our colleagues during Leg 125, especially Mark Simpson, who trained us in data acquisition and entry, and Margaret Burke, who assisted with the measurements. Michael Mottl and Patricia Fryer provided helpful discussions. Darrel Cowan and Mervyn Jones provided careful and constructive reviews, and Dr. Jones pointed out the value of critical-state soil mechanics and the Cam clay model in interpreting our data. Laura Stokking provided valuable scientific and editorial counsel. Post-cruise work was funded by a grant from the United States Science Advisory Committee (USSAC).

\section{REFERENCES}

Barber, A. J., Tjokrosapoetro, S., and Charlton, T. R., 1986. Mud volcanoes, shale diapirs, wrench faults, and mélanges in accretionary complexes, Eastern Indonesia. AAPG Bull., 70:1729-1741.

Barber, T., and Brown, K., 1988. Mud diapirism: the origin of mélanges in accretionary complexes? Geol. Today, 4:89-94.

Bloomer, S., 1983. Distribution and origin of igneous rocks from the landward slopes of the Mariana Trench: implications for its structure and evolution. J. Geophys. Res., 88:7411-7428.

Bolton, M., 1979. A Guide to Soil Mechanics: New York (Halsted Press).

Boyce, R. E., 1977. Deep Sea Drilling Project procedures for shear strength measurement of clayey sediment using modified Wykeham Farrance laboratory vane apparatus. In Barker, P., Dalziel, I.W.D., et al., Init. Repts. DSDP, 36: Washington (U.S. Govt. Printing Office), 1059-1068.

Coleman, R. G., 1971. Petrologic and geophysical nature of serpentinites. Geol. Soc. Am. Bull., 82:897-918.

Cowan, D. S., and Mansfield, C. F., 1970. Serpentinite flows on Joaquin Ridge, Southern Coast Ranges, California. Geol. Soc. Am. Bull., 81:2615-2628.

Fryer, P., Ambos, E. L., and Hussong, D. M., 1985. Origin and emplacement of Mariana forearc seamounts. Geology, 13:774-777.

Fryer, P., and Fryer, G. J., 1987. Origins of nonvolcanic seamounts in a forearc environment. In Keating, B., Fryer, P., and Batiza, R. (Eds.), Seamounts, Islands, and Atolls. Am. Geophys. Union, AGU Geodyn. Ser., 43:61-69.

Fryer, P., Pearce, J. A., Stokking, L. B., et al., 1990. Proc. ODP, Init. Repts., 125: College Station, TX (Ocean Drilling Program).

Handin, J., 1964. Strength at high confining pressure and temperature of serpentinite from Mayaguez, Puerto Rico. In Burk, C. A. (Ed.), A Study of Serpentinite: the AMSOC Core Hole Near Mayaguez, Puerto Rico. Nat. Acad. Sci., Nat. Res. Counc. Publ., 1188:126-131.

Horine, R. L., Moore, G. F., and Taylor, B., 1990. Structure of the outer Izu-Bonin forearc from seismic-reflection profiling and gravity modeling. In Fryer, P., Pearce, J. A., Stokking, L. B., et al., Proc. ODP, Init. Repts., 125: College Station, TX (Ocean Drilling Program), 81-94.

Hussong, D. M., and Fryer, P., 1982. Structure and tectonics of the Mariana arc and fore-arc: drillsite selection surveys. In Hussong, D. M., Uyeda, S., et al., Init. Repts. DSDP, 60: Washington (U.S. Govt. Printing Office), 33-44.

, 1985. Fore-arc tectonics in the northern Mariana arc. In Nasu, N., et al. (Eds.), Formation of Active Ocean Margins: Tokyo (Terrapub), 273-290.

Hyde, A.F.L., and Burke, J. J., 1988. Undrained creep deformation of a strip load on clay. In Cristescu, N., and Ene, H. I. (Eds.), Rock and Soil Rheology: Berlin (Springer-Verlag), 119-149.

Jackson, M.P.A., and Talbot, C. J., 1986. External shapes, strain rates, and dynamics of salt structures. Geol. Soc. Am. Bull., 97:305-323. 
Karig, D. E., 1986. Physical properties and mechanical state of accreted sediments in the Nankai Trough, Southwest Japan Arc. In Moore, J. C. (Ed.), Structural Fabrics in Deep Sea Drilling Project Cores from Forearcs. Mem.-Geol. Soc. Am., 166:117-133.

Kirby, S. H., and McCormick, J. W., 1989. Inelastic properties of rocks and minerals: strength and rheology: section III. In Carmichael, R. S. (Ed.), Practical Handbook of Physical Properties of Rocks and Minerals: Boca Raton, FL (CRC Press), 177-297.

Phipps, S. P., 1984a. Mesozoic ophiolitic olistostromes and Cenozoic imbricate thrust faulting in the northern California Coast Ranges: geology of the Mysterious Valley area, Napa County [Ph.D. dissert.]. Princeton Univ., Princeton, New Jersey.

, 1984b. Ophiolitic olistostromes in the basal Great Valley sequence, Napa County, northern California Coast Ranges. In Raymond, L. (Ed.), Melanges: Their Nature, Origin, and Significance: Spec. Pap.-Geol. Soc. Am., 198:103-125.

Phipps, S. P., and Shipboard Party, ODP Leg 125, 1990. Serpentinite mud volcanoes in the Mariana-Bonin forearc: mechanics and implications for subduction zone evolution. Geol. Soc. Am. Abstracts, 22:A223. (Abstract)
Raleigh, C. B., and Paterson, M. S., 1965. Experimental deformation of serpentinite and its tectonic implications. J. Geophys. Res., 70:3965-3985.

Taylor, B., and Smoot, N. C., 1984. Morphology of Bonin forearc submarine canyons. Geology, 12:724-727.

Westbrook, G. K., and Smith, M. J., 1983. Long décollements and mud volcanoes: evidence from the Barbados Ridge Complex for the role of high pore fluid pressures in the development of an accretionary complex. Geology, 11:279-283.

Wood, D. M., 1990. Soil Behaviour and Critical State Soil Mechanics: Cambridge (Cambridge Univ. Press).

Date of initial receipt: 4 October 1990

Date of acceptance: 6 September 1991

Ms 125B-154 